\title{
Molten-Salt-Assisted Self-Assembly (MASA)-Synthesis of Mesoporous Metal Titanate-Titania, Metal Sulfide-Titania, and Metal Selenide-Titania Thin Films
}

\author{
Cüneyt Karakaya, Yurdanur Türker, and Ömer Dag*
}

\begin{abstract}
New synthetic strategies are needed for the assembly of porous metal titanates and metal chalcogenite-titania thin films for various energy applications. Here, a new synthetic approach is introduced in which two solvents and two surfactants are used. Both surfactants are necessary to accommodate the desired amount of salt species in the hydrophilic domains of the mesophase. The process is called a molten-salt-assisted self-assembly (MASA) because the salt species are in the molten phase and act as a solvent to assemble the ingredients into a mesostructure and they react with titania to form mesoporous metal titanates during the annealing step. The mesoporous metal titanate (meso- $\mathrm{Zn}_{2} \mathrm{TiO}_{4}$ and meso- $\mathrm{CdTiO}_{3}$ ) thin films are reacted under $\mathrm{H}_{2} \mathrm{~S}$ or $\mathrm{H}_{2} \mathrm{Se}$ gas at room temperature to yield high quality transparent mesoporous metal chalcogenides. The $\mathrm{H}_{2} \mathrm{Se}$ reaction produces rutile and brookite titania phases together with nanocrystalline metal selenides and $\mathrm{H}_{2} \mathrm{~S}$ reaction of meso- $\mathrm{CdTiO}_{3}$ yields nanocrystalline anatase and $\mathrm{CdS}$ in the spatially confined pore walls. Two different metal salts (zinc nitrate hexahydrate and cadmium nitrate tetrahydrate) are tested to demonstrate the generality of the new assembly process. The meso- $\mathrm{TiO}_{2}-\mathrm{CdSe}$ film shows photoactivity under sunlight.
\end{abstract}

\section{Introduction}

Many new synthetic strategies for nanoscale, multi component, and photoactive thin films have been intensively investigated in order to develop a new generation of materials for photocatalysis and energy related applications. ${ }^{[1]}$ For example, the modification of nano-titania, by doping or sensitizing using a semiconductor quantum dot (QD) or a dye molecule to improve its sun light absorption for solar cell and photocatalysis applications, is currently one of the most active fields in synthetic chemistry. ${ }^{[2]}$ Mesoporous multicomponent transition metal oxides are also target materials for these applications, due to their unique electronic properties, which can be manipulated using the size, shape, and composition. ${ }^{[3]}$ Synthesizing mesoporous titania thin films using triblock copolymers ${ }^{[4]}$ through evaporation

C. Karakaya, Dr. Y. Türker, Prof. Ö. Dag

Bilkent University

Department of Chemistry

06800, Ankara, Turkey

E-mail:dag@fen.bilkent.edu.tr

DOI: 10.1002/adfm.201202716 induced self-assembly (EISA) ${ }^{[5]}$ and modifying them with chalcogenide QDs ${ }^{[6]}$ has been the topic of many investigations. The QDs are either incorporated into the pores through infiltration ${ }^{[6 a]}$ or produced by reacting $\mathrm{Cd}^{\mathrm{II}}$ ions, impregnated or incorporated into the pores using a lyotropic liquid crystalline (LLC) templating approach, ${ }^{[6 b, 6 c]}$ under an $\mathrm{H}_{2} \mathrm{~S}$ or $\mathrm{H}_{2} \mathrm{Se}$ atmosphere. The LLC approach has also been employed to make thin films of mesoporous metals ${ }^{[7]}$ and semiconductors ${ }^{[8]}$; these materials cannot be prepared using common synthesis methods. However the incorporation of metal ions into the pores through impregnation is quite challenging and results in a limited amount of metal oxides with a nonuniform distribution (size and shape) in the pores. ${ }^{[6 b]}$ Designing metal oxidetitania or metal titanate thin films with a well-defined structure and composition is still the major challenge in metal oxide chemistry. ${ }^{[9]}$

We recently found that salt-surfactant LLC self-assembly occurs because the salt melts and acts as a solvent in the assembly process. ${ }^{[10]}$ Note also that in a confined space (the hydrophilic domains of the mesophase), the melting point of the salt drops drastically and the molten salt never crystallize even down to liquid nitrogen temperatures due to the soft confinement effect (SCE). ${ }^{[10]}$ The addition of a charged surfactant to the salt-oligo(ethylene oxide) non-ionic surfactant LLC phase further increases the amount of salt in the LLC mesophase. ${ }^{[11]}$ Collaborative assembly of these two surfactants and the interaction of the charged hydrophilic-hydrophobic interface of the surfactant domains in the LLC mesophase, with the molten salt domains further stabilize the salt-surfactant LLC mesophases. ${ }^{[11]}$ Note also that the SCE and hard confinement effect (HCE) have also been collaboratively used to determine the pore size of the mesoporous materials ${ }^{[12]}$ and to prepare multifunctional mesoporous thin films. ${ }^{[13]}$

Here, we introduce a new self-assembly process, called molten-salt-assisted self-assembly (MASA), that uses two surfactants $\left(\mathrm{CTAB} / \mathrm{C}_{12} \mathrm{EO}_{10}\right.$ with a 1.0 mole ratio, where CTAB is cethyltrimethylammonium bromide and $\mathrm{C}_{12} \mathrm{EO}_{10}$ is 10-lauryl ether) and two solvents to produce mesoporous metal titanate thin films. One of the solvents is volatile (ethanol) and is used to ensure a homogeneous mixture of the ingredients (very 
As coated

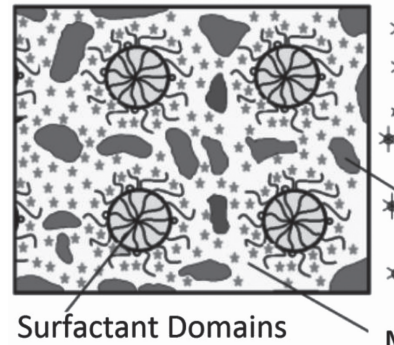

Surfactant Domains
Molten Salt-Titania
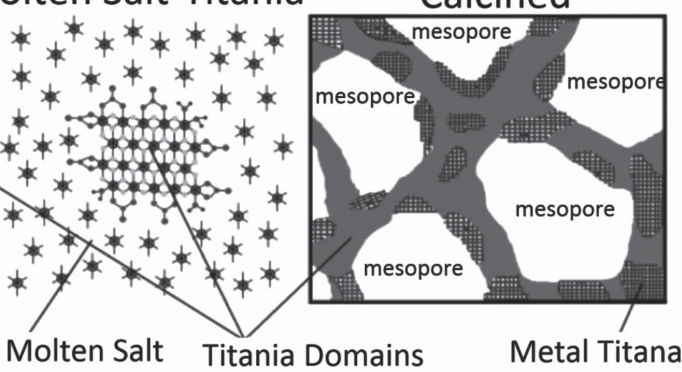

-Metal Ion •Nitrogen • Oxygen • Titanium • Hydrogen

Scheme 1. Schematic representation of meso-domains of the as-prepared (left) and calcined thin films. the MASA process, such that without CTAB the amount of salt that can be incorporated into mesostructure is limited..$^{[6 c]}$ Moreover, the addition of the CTAB to salt- $\mathrm{C}_{12} \mathrm{EO}_{10}$ LLC phase, ${ }^{[11]}$ or the above sol-gel media, stabilizes the mesophase or mesostructured solid, respectively, at relatively high salt concentrations. ${ }^{[13]}$ As a result, the metal ion to $\mathrm{Ti}^{\mathrm{IV}}$ mole ratio can be increased up to 1.43 . The nitric acid is used for two reasons: i) the necessity of an acidic media for the slow hydrolysis and condensation of $\mathrm{TTB}^{[4]}$ and ii) the nitrate ion is an hydrotropic anion in the LLC media ${ }^{[14]}$ and can be decomposed at a relatively low temperature. ${ }^{[6 c]}$ important for the spin coating process) and the other (molten salt, zinc nitrate hexahydrate or cadmium nitrate tetrahydrate) is non-volatile and is used to keep the self-assembled mesostructure at moderately higher temperatures during calcination. In the final products, the $\mathrm{Zn}^{\mathrm{II}}$ or $\mathrm{Cd}^{\mathrm{II}}$ to $\mathrm{Ti}^{\mathrm{IV}}$ mole ratios were varied between 0.29 and 1.14 (corresponding to $2 / 7$ and $8 / 7$ mole ratio of $\mathrm{M} / \mathrm{Ti}$, where $\mathrm{M}$ is $\mathrm{Zn}$ or $\mathrm{Cd}$ for each $\mathrm{C}_{12} \mathrm{EO}_{10}$ ) while all the other ingredient concentrations were kept constant.

\section{Results and Discussion}

Spin coating of a clear ethanol solution of $\mathrm{C}_{16} \mathrm{H}_{33} \mathrm{~N}\left(\mathrm{CH}_{3}\right)_{3} \mathrm{Br}$ (CTAB), $\mathrm{C}_{12} \mathrm{H}_{25}\left(\mathrm{OCH}_{2} \mathrm{CH}_{2}\right){ }_{10} \mathrm{OH}\left(\mathrm{C}_{12} \mathrm{EO}_{10}\right)$, concentrated nitric acid $\left(\mathrm{HNO}_{3}\right)$, titanium(IV) butoxide (n-butyl) $\left(\mathrm{Ti}\left(\mathrm{OC}_{4} \mathrm{H}_{9}\right)_{4}, \mathrm{TTB}\right)$ and $\left[\mathrm{Zn}\left(\mathrm{H}_{2} \mathrm{O}\right)_{6}\right]\left(\mathrm{NO}_{3}\right)_{2}$ (or $\left.\left[\mathrm{Cd}\left(\mathrm{H}_{2} \mathrm{O}\right)_{4}\right]\left(\mathrm{NO}_{3}\right)_{2}\right)$ (with mole ratios of $1.0,1.0,7.0,7.0$ and $\mathrm{x}$, respectively, and $\mathrm{x}$ is between 2.0 and 10) over a substrate forms a gel-like thin film. The salt species in the freshly prepared films never crystallize out even in an ice bath up to a 10 salt $/ \mathrm{C}_{12} \mathrm{EO}_{10}$ mole ratio (where $\mathrm{Zn} / \mathrm{Ti}=1.43$ ); which means that the metal salt-titania species in the as-prepared samples form a complex stable liquid that assembles with the surfactant molecules into mesostructured films (Scheme 1). The compositions of the initial homogeneous solutions are tabulated in Table 1 . The role of CTAB is also very important in

Table 1. The amount of ingredients and the metal ion titanium mole ratio in the solutions and in the final products, mesoporous zinc titanates and cadmium titanates.

\begin{tabular}{|c|c|c|c|}
\hline \multicolumn{2}{|c|}{ meso- $\mathrm{Zn}_{2} \mathrm{O}_{4}$} & \multicolumn{2}{|c|}{ Meso-CdTiO $_{3}$} \\
\hline $\begin{array}{l}\mathrm{Zn}{ }^{\prime \prime} / \mathrm{Ti}^{\mathrm{IV}} \\
\text { [mole ratio] }\end{array}$ & $\begin{array}{c}\left.\mathrm{Zn}\left(\mathrm{H}_{2} \mathrm{O}\right)_{6}\right]\left(\mathrm{NO}_{3}\right)_{2} \\
{[\mathrm{~g}]}\end{array}$ & $\begin{array}{c}\mathrm{Cd}^{\mathrm{II}} / \mathrm{Ti}^{\mathrm{IV}} \\
\text { [mole ratio] }\end{array}$ & $\begin{array}{c}\left.\mathrm{Cd}\left(\mathrm{H}_{2} \mathrm{O}\right)_{4}\right]\left(\mathrm{NO}_{3}\right)_{2} \\
{[\mathrm{~g}]}\end{array}$ \\
\hline 0.29 & 0.48 & 0.29 & 0.49 \\
\hline 0.57 & 0.95 & 0.57 & 0.98 \\
\hline 0.86 & 1.43 & 0.86 & 1.48 \\
\hline 1.14 & 1.90 & 1.14 & 1.97 \\
\hline 1.43 & 2.38 & & \\
\hline 1.71 & 2.85 & & \\
\hline
\end{tabular}

The CTAB, $\mathrm{C}_{12} \mathrm{EO}_{10}$, concentrated $\mathrm{HNO}_{3}, \mathrm{Ti}\left(\mathrm{OC}_{4} \mathrm{H}_{9}\right)_{4}$, and ethanol, are constant in all samples and are $0.29,0.50,0.50,1.90 \mathrm{~g}$, and $7.00 \mathrm{~mL}$, respectively. The only source for water is the coordinated water molecules in the salt.

\subsection{Mesostructured Salt-Titania Thin Films}

The fresh films diffract a single line at $1.56^{\circ}, 2 \theta(56.6 \AA$, d-spacing), Figure 1. It is difficult to identify the mesophases with increasing salt content, since they only provide a single diffraction line. Supporting Information Figure S1 shows a typical high angle X-ray diffraction (XRD) pattern of a fresh sample, indicating that the salt species remain liquid in the mesostructure without crystallization. Also note that the POM images of the films are dark between the crossed polarizers (no birefringence), collectively indicating the presence of an isotropic mesostructure. The d-spacing, obtained using these two surfactants, is about 1-2 nm larger than a typical spacing in a mesostructured silica or titania, prepared using CTAB and $\mathrm{C}_{12} \mathrm{EO}_{10}$ individually. The likely origin of this shift (enlargement) is the melted salt species that expands the unit cell (Scheme 1). Note also that a similar behavior is also observed in the salt-two

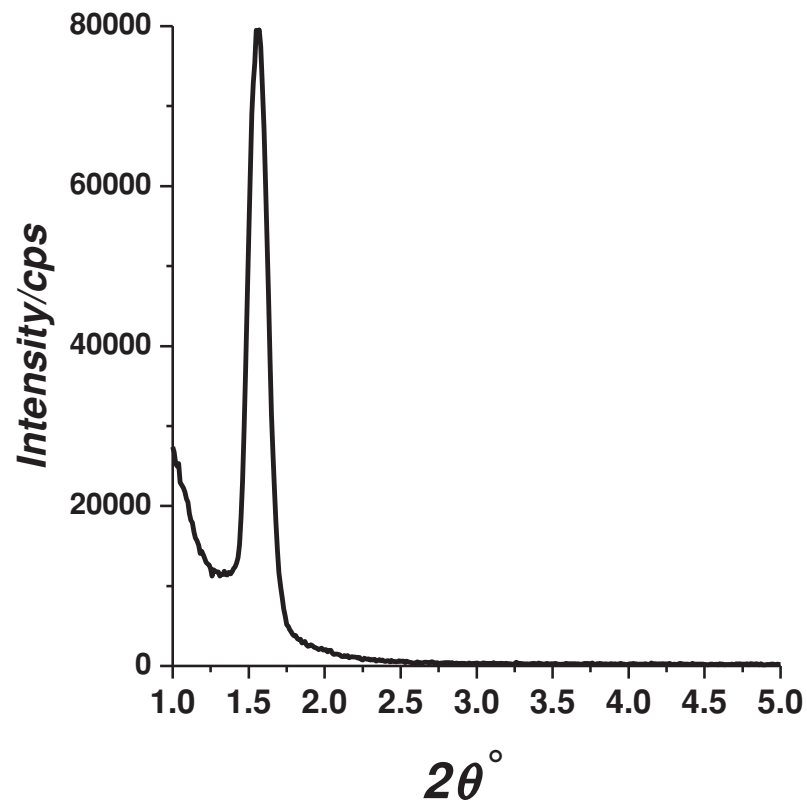

Figure 1. XRD pattern of a fresh mesostructured $\left.\mathrm{Zn}\left(\mathrm{H}_{2} \mathrm{O}\right)_{6}\right]\left(\mathrm{NO}_{3}\right)_{2} /$ $\mathrm{TiO}_{2}$. 
(a) 2.5

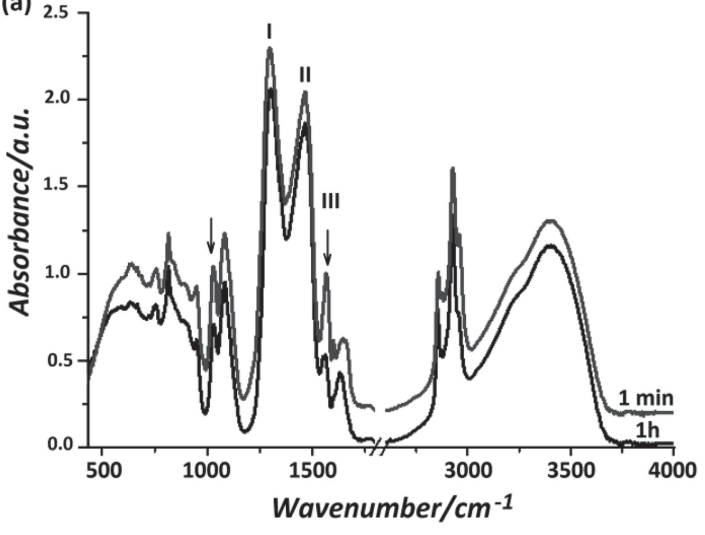

(b)

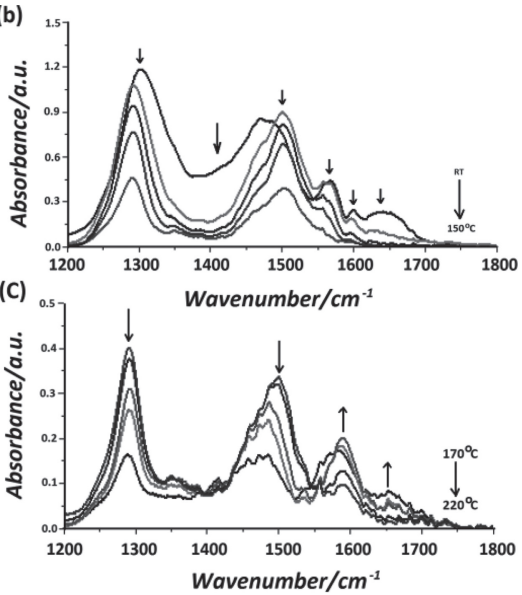

Figure 2. a) FTIR spectra of a fresh sample of mesostructured cadmium loaded titania. b,c) FTIR spectral changes during calcination of mesostructured zinc loaded titania. The temperature range is indicated on the spectra and arrows show the direction of change.

surfactant LLC mesophases, in which the unit cell expands as a function of the amount of salt in the media. ${ }^{[11]}$

The fresh film, coated over a silicon wafer, was monitored using Fourier transform infrared (FTIR) spectroscopy at room temperature (RT) and aging at higher temperatures to elucidate the nature of the salt and titania species. The peaks at 1291 and $1470 \mathrm{~cm}^{-1}$ in the freshly prepared $\mathrm{Cd}^{\mathrm{II}}$ samples are due to the antisymmetric stretching mode of the nitrate ion, coordinated to the $\mathrm{Cd}^{\mathrm{II}}$ ion and the peak at $1563 \mathrm{~cm}^{-1}$ is due to the antisymmetric stretching mode of the nitrate ion coordinated to the titania species. ${ }^{[6,15]}$ Note also that the spectrum of the freshly prepared films looks very similar to the spectrum of the molten $\left[\mathrm{Cd}\left(\mathrm{H}_{2} \mathrm{O}\right)_{4}\right]\left(\mathrm{NO}_{3}\right)_{2}$ except for the peaks due to the nitrates on the titania surface, indicating a liquid salt and solid titania particles in the film. The peak at $1563 \mathrm{~cm}^{-1}$ gradually decreases in intensity over time at RT, indicating a growth of titania domains and a reduction of the titania surface sites for nitrate coordination (Figure 2a and Scheme 1). Note also that the spectral changes in the $\left[\mathrm{Zn}\left(\mathrm{H}_{2} \mathrm{O}\right)_{6}\right]\left(\mathrm{NO}_{3}\right)_{2}$-titania samples are very similar. Overall, the liquid salt and titania species form a stable solution in the hydrophilic domains of the mesostructure that keeps the salt species in the liquid phase, due to the SCE, at high salt concentrations (Scheme 1). This is a well-known physicochemical behavior of solutions (known as colligative properties and depression of the melting point of solvents in the presence of impurities). Therefore similar physicochemical phenomena are happening in a confined space at much lower temperatures ${ }^{[10]}$ in the hydrophilic domains of the mesophases. Otherwise, it is impossible to keep the salt species in the mesostructures at such high concentrations (higher than the solubility limit of the salts in water). This behavior is quite unusual and can be used to design new materials.

To further understand the system, the fresh $\mathrm{Zn}^{\mathrm{II}}$ containing samples were also monitored using FTIR spectroscopy at RT over time and during calcination. The coordinated nitrate peaks, at 1291 and $1500 \mathrm{~cm}^{-1},{ }^{[14]}$ increase in intensity due to the dehydration of the films and then they start to decline in intensity at temperatures above $60{ }^{\circ} \mathrm{C}$. The peak, at $1563 \mathrm{~cm}^{-1}$, due to the nitrate ion coordinated to the titania surface ${ }^{[6 c]}$ also decreases in intensity during heating and disappears around $150{ }^{\circ} \mathrm{C}$. However, above $170{ }^{\circ} \mathrm{C}$, a new peak, at around $1589 \mathrm{~cm}^{-1}$, appears and intensifies up to $190^{\circ} \mathrm{C}$, (Figure $2 \mathrm{~b}, \mathrm{c}$ ). All the nitrate peaks gradually decrease and then disappear upon completion of the calcination process. These observations show that the metal nitrate species are present in the mesostructure and slowly react with the condensing amorphous titania walls to form metal titanate at temperatures above $170{ }^{\circ} \mathrm{C}$. The nanocrystalline zinc titanate starts forming at around $250{ }^{\circ} \mathrm{C}$ (Supporting Information Figure S2a,b). The calcination of the films yields mesoporous zinc titanates up to $1.14 \mathrm{Zn} / \mathrm{Ti}$ mole ratios. At the mole ratios above $1.14 \mathrm{Zn} / \mathrm{Ti}$, wurtzite crystalline $\mathrm{ZnO}$ are also observed in the films, indicating that the mesostructure spills out some of the salt that decomposes into bulk crystalline $\mathrm{ZnO}$.

\subsection{Mesoporous meso- $\mathrm{Zn}_{2} \mathrm{TiO}_{4}$ and meso-CdTiO 3 Thin Films}

The small angle diffraction line of the mesostructured fresh film broadens and disappears during calcination. Since there is a single diffraction line in the XRD pattern, it is not possible to identify the structural and phase changes during the calcination step. However, the $\mathrm{N}_{2}$ adorption-desoption data of zinc titanate and cadmium titanate powders, obtained by scraping tens of films over glass microscope slides, display type IV isotherms with a hysteresis in the desorption branch (Figure 3a and Supporting Information Figure S3). The isotherms and related data are characteristic of mesoporous materials with a relatively narrow pore size distribution (Figure 3a and Supporting Information Figure S3). The average BET surface areas, BJH pore volumes and pore size distributions of the mesoporous thin films using desorption branch are ca. $146 \mathrm{~m}^{2} / \mathrm{g}, 0.09 \mathrm{~cm}^{3} / \mathrm{g}$, and $29 \AA$ for the $\mathrm{Zn} / \mathrm{Ti}$ mole ratio of 0.57 , ca. $230 \mathrm{~m}^{2} / \mathrm{g}$, $0.18 \mathrm{~cm}^{3} / \mathrm{g}$, and $31 \AA$ for the $\mathrm{Zn} / \mathrm{Ti}$ mole ratio of 0.86 and ca. $208 \mathrm{~m}^{2} / \mathrm{g}, 0.20 \mathrm{~cm}^{3} / \mathrm{g}$, and $35 \AA$ for the $\mathrm{Zn} / \mathrm{Ti}$ mole ratio of 1.14 , respectively.

The wide angle XRD patterns of the mesoporous zinc titanate powders (scraped from tens of films over microscope 

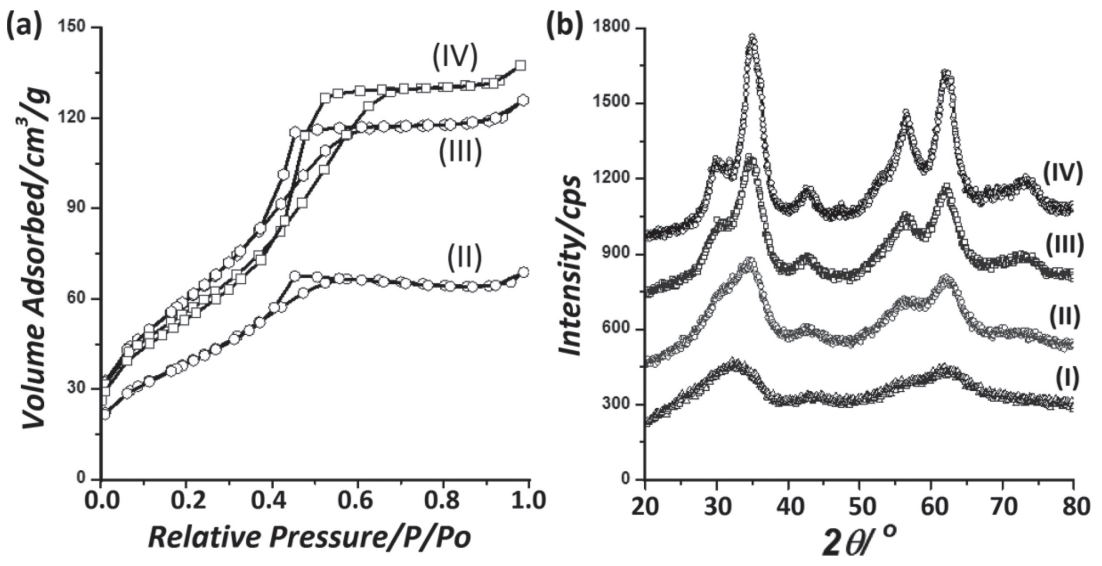

Figure 3. a) $\mathrm{N}_{2}$ sorption isotherms and b) XRD patterns of meso- $\mathrm{Zn}_{2} \mathrm{TiO}_{4}$ with $\mathrm{Zn} / \mathrm{Ti}$ mole ratios of I) 0.29 , II) 0.57 , III) 0.86 , and IV) 1.14 .

glass slides) display broad diffraction lines of zinc titanate ${ }^{[16]}$ at $30.0,34.7,42.7,53.5,56.5,62$, and $72.4^{\circ}, 2 \theta$, (Figure $3 \mathrm{~b}$ and Supporting Information Figure S2), and can be indexed to (220), (311), (400), (422), (511), (440), and (533) planes, respectively, (see ICDD PDF \#00-025-1164, space group of Fd3m, dubbed meso- $\mathrm{Zn}_{2} \mathrm{TiO}_{4}$ (Figure $3 \mathrm{~b}$ and Supporting Information Figure S2 and Table S1) for detailed analysis of the XRD data). The XRD lines of the meso- $\mathrm{Zn}_{2} \mathrm{TiO}_{4}$ are quite broad in the samples with low $\mathrm{Zn} / \mathrm{Ti}$ mole ratios (Figure $3 \mathrm{~b}$ ), indicating an amorphous or ultrasmall nanocrystalline $\mathrm{Zn}_{2} \mathrm{TiO}_{4}$ pore-walls. The optimum $\mathrm{Zn} / \mathrm{Ti}$ mole ratio is between 0.57 and 1.14 (Figure $3 \mathrm{~b}$ and Supporting Information Figure S2a,b). The particle size calculated from the XRD patterns of meso- $\mathrm{Zn}_{2} \mathrm{TiO}_{4}$ (where $\mathrm{Zn}$ / Ti mole ratio is 0.86 ) using Scherer's equation is on average ca. $2.4 \mathrm{~nm}(24 \AA)$, which is the likely nanocrystalline wall thickness at $450{ }^{\circ} \mathrm{C}$ in the meso- $\mathrm{Zn}_{2} \mathrm{TiO}_{4}$ and it gradually increases with an increasing $\mathrm{Zn}^{\mathrm{II}}$ content and calcination temperature (Figure $3 \mathrm{~b}$ and Supporting Information Figure S3a,b). Notice also that the structure of the meso- $\mathrm{Zn}_{2} \mathrm{TiO}_{4}$ is stable up to $650{ }^{\circ} \mathrm{C}$ (at this temperature the only crystalline phase is $\mathrm{Zn}_{2} \mathrm{TiO}_{4}$ with a particle size ca. $40 \AA$, likely the pore-wall thickness) and it starts growing around this temperature by leaching out another phase of a highly crystalline tetragonal zinc titanate at around $750{ }^{\circ} \mathrm{C}$. Notice also that the $\mathrm{Zn}_{2} \mathrm{TiO}_{4}$ nanocrystallite is ca. $6.2 \mathrm{~nm}$ at $750{ }^{\circ} \mathrm{C}$ (Supporting Information Figure S2b). The low temperature diffraction patterns are very broad and difficult to assign the crystal structure of the zinc titanate phase, however XRD lines of the same samples at higher temperatures $\left(650-750{ }^{\circ} \mathrm{C}\right)$ are sharp enough to index them and unambiguously assign the structure to the $\mathrm{Zn}_{2} \mathrm{TiO}_{4}$ phase. This conflicts with the observation of $\mathrm{Li}$ et $\mathrm{al},{ }^{[9]}$ who assigned the XRD patterns of their samples to $\mathrm{ZnTiO}_{3}$. The XRD pattern and Raman spectra (details are given later in the text) of these two titanates are quite different, therefore the zinc titanate synthesized by Li et al. ${ }^{[9]}$ needs further investigation using Raman spectroscopy.

The calcined films have high optical quality, are crack free, and absorb strongly in the UV region of the electromagnetic radiation (Supporting Information Figure S4a). The low energy absorption edge displays a blue shift with an increasing $\mathrm{Zn}^{\mathrm{II}}$ content of the films (Supporting Information Figure S4), indicating an increase in the $\mathrm{Zn}_{2} \mathrm{TiO}_{4}$ component of the pore-walls.
Fitting the absorption-edge using a direct gap relation (Tauc-plot) provides the bandgap values, ${ }^{[17,18]}$ ca. $3.54,3.72,3.85,3.92$, and $3.97 \mathrm{eV}$ for the calcined samples of meso$\mathrm{Zn}_{2} \mathrm{TiO}_{4}$ with a $\mathrm{Zn} / \mathrm{Ti}$ mole ratio of 0.00 , $0.29,0.57,0.86$, and 1.14 , respectively (Supporting Information Figure S4b). The FTIR spectra of the same series display broad features with increasing intensities at 440,512 , and $622 \mathrm{~cm}^{-1}$ and a shoulder on the higher energy site with increasing $\mathrm{Zn}^{\mathrm{II}}$ in the samples (Supporting Information Figure $\mathrm{S} 5 \mathrm{a}$ ). The Raman spectra of the meso- $\mathrm{Zn}_{2} \mathrm{TiO}_{4}$, at all compositions, display broad peaks, at $228,262,311,345,401,532 \mathrm{~cm}^{-1}$, which are characteristic of the $\mathrm{Zn}_{2} \mathrm{TiO}_{4}$ nanocrystallites ${ }^{[19]}$ up to $650{ }^{\circ} \mathrm{C}$, and are consistent with the XRD results (Supporting Information Figure S5b,c). The Raman peaks, like the XRD lines, become sharper and better resolved upon further heating between 650 and $750{ }^{\circ} \mathrm{C}$, due to the growth and phase transformations of the nanocrystalline zinc titanate. These spectral changes and changes in the XRD patterns with heat treatment collectively show that the films are stable as $\mathrm{Zn}_{2} \mathrm{TiO}_{4}$ up to $650{ }^{\circ} \mathrm{C}$, above which the mesoporous zinc titanate spills out bulk tetragonal zinc titanate crystals (Supporting Information Figure S2b,S5c).

Figure 4 is a STEM image with an EDS line scan that shows the $\mathrm{Zn}, \mathrm{Ti}$, and $\mathrm{O}$ composition along the line, clearly illustrating the homogenous distribution of both $\mathrm{Ti}$ and $\mathrm{Zn}$ throughout the film. Figure $5 \mathrm{a}-\mathrm{d}$ is TEM images of meso- $\mathrm{Zn}_{2} \mathrm{TiO}_{4}$ thin films, showing sponge like mesoporosity. Figure $5 \mathrm{~d}$ displays a HRTEM image, showing the crystalline domains on the pore walls, typically in the range of $1-3 \mathrm{~nm}$, and correlating with the

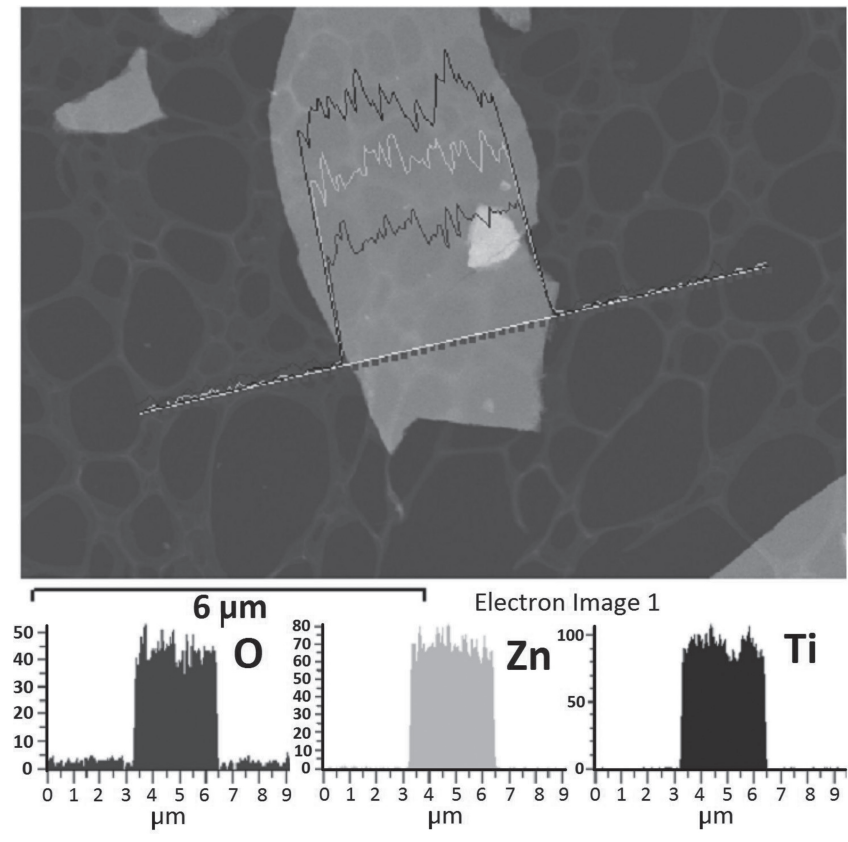

Figure 4. STEM image of meso- $\mathrm{Zn}_{2} \mathrm{TiO}_{4}$ film with $\mathrm{O}$ (black, left), $\mathrm{Zn}$ (gray, middle), and Ti (black, right) EDS line scan data. 

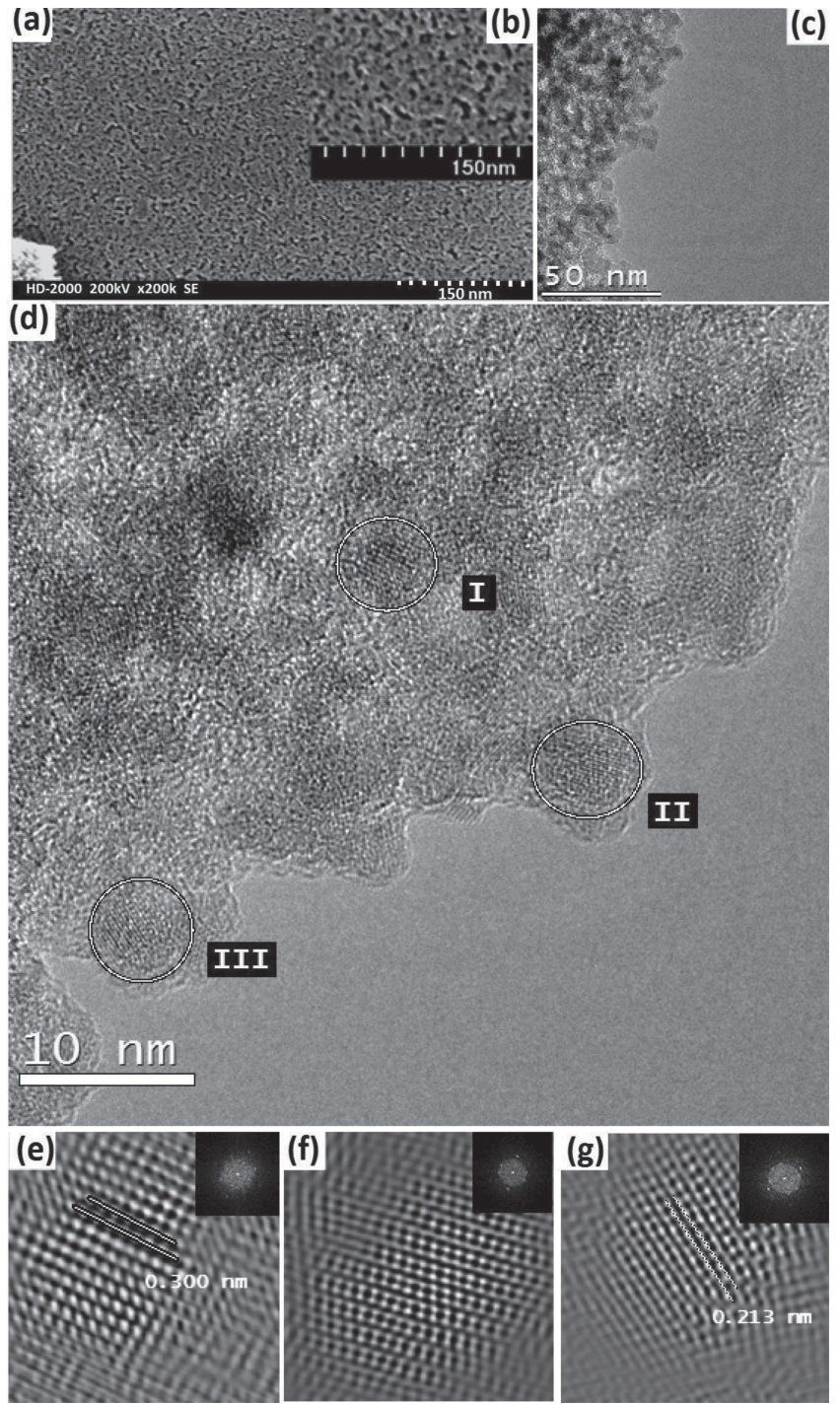

Figure 5. a-d) The TEM images of the meso- $\mathrm{Zn}_{2} \mathrm{TiO}_{4}$ with various magnification. The FFTs (insets) and back FFTs of the selected areas in the circle, in the panel (d), of I (e), II (f), and III (g).

observed broad XRD lines and broad FTIR and Raman features. A detailed analysis of the HRTEM images done by taking the fast Fourier transform (FFT) and inverse FFT of a selected area (marked in a circle in Figure 5d) reveals lattice spots and fringes that originate from the nanocrystalline $\mathrm{Zn}_{2} \mathrm{TiO}_{4}$ domains. The lattice fringes observed in various parts of the meso- $\mathrm{Zn}_{2} \mathrm{TiO}_{4}$ correspond to (210) or (211), (220), and (312) planes with spacing of $0.261,0.213$, and $0.173 \mathrm{~nm}$, respectively, and are consistent with the XRD data.

The small angle diffraction line in the fresh films of $\mathrm{Cd}^{\mathrm{II}}$ samples is also lost upon calcination, but the $\mathrm{N}_{2}$ sorption data display type IV isotherms, characteristic of mesoporous materials (Supporting Information Figure S3a). The XRD and $\mathrm{N}_{2}$ sorption data collectively show that the mesopores in the meso$\mathrm{CdTiO}_{3}$ films are similar to meso- $\mathrm{Zn}_{2} \mathrm{TiO}_{4}$ films. The wide angle XRD patterns of the powder, obtained by scraping tens of thin films or a few dip coated, spray coated or casted thicker films, display broad diffraction lines, originating from the cadmium titanate $\left(\mathrm{CdTiO}_{3}\right)$ pore walls (Supporting Information Figure $\mathrm{S6}$ ). Further heating the films ensures further crystallization and growth of the $\mathrm{CdTiO}_{3}$ phase. The XRD pattern, obtained from the samples heated at $550{ }^{\circ} \mathrm{C}$, displays diffraction lines that can be indexed to rhombohedral $\mathrm{CdTiO}_{3}$ with a space group of R-3 (ICDD PDF\#00-029-0277) (Supporting Information Figure S6). The Raman spectrum of meso- $\mathrm{CdTiO}_{3}$ also displays broad features between the 200 and $1000 \mathrm{~cm}^{-1}$ region, however annealing at $550{ }^{\circ} \mathrm{C}$ results in sharp peaks, which are useful to identify the meso- $\mathrm{CdTiO}_{3}$ films (Supporting Information Figure S6 and Table S1). The peaks at 215, 245, 327, 462, 598, and $698 \mathrm{~cm}^{-1}$ are due to crystalline ilmenite phase of $\mathrm{CdTiO}_{3}$, and the weak peaks at $142,297,396,510$, and $633 \mathrm{~cm}^{-1}$ are due to crystalline anatese phase of $\mathrm{TiO}_{2}$. It means that the $\mathrm{CdTiO}_{3}$ and excess $\mathrm{TiO}_{2}$ sites separately crystallize into their bulk phases upon annealing at $550{ }^{\circ} \mathrm{C}$, at which point the mesostructures collapse.

\subsection{Thicker Mesoporous Zinc Titanate and Cadmium Titanate Films and Monoliths}

Dip coating (by dipping glass slides into a clear solution of the ingredients with the same composition used for spin coating and pulling with a speed of $0.4 \mathrm{~mm} / \mathrm{s}$ ), spray coating and casting of the initial mixture produce mesostructured films and monoliths, respectively, and produce large quantities of mesoporous metal titanate upon calcination. However, the samples casted with high salt concentrations (over $0.86 \mathrm{M} / \mathrm{Ti}$ ) also produce bulk metal oxide (Supporting Information Figure S7). The casting method works effectively at lower salt concentrations, but the dip coated and stray coated samples (thinner films) can be calcined into mesoporous metal titanates, up to $1.14 \mathrm{M} /$ Ti mole ratios, without producing any bulk metal oxide phases. A careful analysis of the spray coated films provides insight into the MASA process. During spray coating, the fine droplets of the mixture homogenously lose ethanol during their trip from the nozzle of the spray to the surface of the substrate; the droplets coat the substrate with the remaining composition (mainly the secondary solvent, molten salt, surfactant and titania species). The homogeneous mixture without ethanol is a liquid crystalline gel-like film that over time, solidifies into a mesostructured thick film, and can be calcined to mesoporous metal titanate (Supporting Information Figure S6). Supporting Information Figure S8 shows two small angle XRD patterns of the as-sprayed films before and after applying a shear force. The diffraction intensity increases by 4 times, indicating some degree of orientation in the mesostructured gel with a gentle shear force and liquid crystalline like behavior in the as-sprayed fresh films. This behavior also supports our proposal that the molten phase assembles the mixture of all the ingredients first into a liquid crystalline mesophase, which then solidifies into a mesostructured solid upon aging. The same principle is valid for the thinner dip coated samples, where the primary solvent can be homogenously evaporated out without crystallization of the salt species to produce mesoporous metal titanates after calcination. 
The wide angle XRD patterns of the calcined meso- $\mathrm{Zn}_{2} \mathrm{TiO}_{4}$ and meso-CdTiO ${ }_{3}$ of the spray coated, dip coated and casted samples also display diffraction lines similar to thin films and can be indexed to $\mathrm{Zn}_{2} \mathrm{TiO}_{4}$ and $\mathrm{CdTiO}_{3}$, respectively (Supporting Information Figure $\mathrm{S} 6 \mathrm{a}, \mathrm{c}$ ). The $\mathrm{N}_{2}$ sorption isotherms of the thicker films also show Type IV with $\mathrm{H} 2$ hysteresis, characteristic of mesoporous materials with a very similar pore size distribution and surface area (Supporting Information Figure S6d). Similar to spin coated samples, the DP coated meso- $\mathrm{CdTiO}_{3}$ samples leach out a highly crystalline rhombohedral $\mathrm{CdTiO}_{3}$ at around $550{ }^{\circ} \mathrm{C}$, indicating a collapse of the mesopores. The Raman spectra of the same samples display very broad peaks that become sharp at $550{ }^{\circ} \mathrm{C}$ (Supporting Information Figure $\mathrm{S} 6 \mathrm{~b})$. These data collectively prove that the structure and composition of the meso- $\mathrm{Zn}_{2} \mathrm{TiO}_{4}$ and meso$\mathrm{CdTiO}_{3}$ thick films are similar to thin films. Therefore the spray method can be employed when large quantities and thicker samples are necessary.

\subsection{Fabrication of Mesoporous Metal Chalcogenide-Titania Thin Films}

The thin films, meso- $\mathrm{CdTiO}_{3}$ and meso- $\mathrm{Zn}_{2} \mathrm{TiO}_{4}$ (with a $\mathrm{Cd} / \mathrm{Ti}$ mole ratio of 0.57 and $\mathrm{Zn} / \mathrm{Ti}$ mole ratio of 0.86 ), were separately exposed to $\mathrm{H}_{2} \mathrm{~S}$ and $\mathrm{H}_{2} \mathrm{Se}$ gas under a controlled atmosphere in order to produce mesoporous titania-metal sulfide (dubbed meso- $\mathrm{TiO}_{2}-\mathrm{MS}$, where $\mathrm{M}$ is $\mathrm{Cd}$ ) and mesoporous titania-metal selenide (dubbed meso- $\mathrm{TiO}_{2}-\mathrm{MSe}$, where $\mathrm{M}$ is $\mathrm{Cd}$ or $\mathrm{Zn}$, respectively). Figure 6a-c shows the XRD patterns of meso-CdTiO ${ }_{3}$, meso- $\mathrm{TiO}_{2}$-CdS and meso- $\mathrm{TiO}_{2}$-CdSe, respectively. The diffraction lines are very broad, which makes the identification of the nanocrystalline phases difficult, Figure 6. However, Raman spectroscopy is very useful and provides insight into the structure of the titania phases. ${ }^{[19]}$ Figure $6 \mathrm{~d}$ shows the Raman spectra of the meso- $-\mathrm{CdTiO}_{3}$, meso- $\mathrm{TiO}_{2}-\mathrm{CdS}$, and meso- $\mathrm{TiO}_{2}$-CdSe thin films. Note also that the titania-metal chalcogenide thin films are still mesoporous, see discussion in the photo-activity section, but the $\mathrm{N}_{2}$ sorption data is difficult to collect; the samples, under vacuum and heat treatment for dehydration, leach out the metal chalcogenides and deposits on the surface of sample holder (Supporting Information Figure S3b). Therefore the $\mathrm{N}_{2}$ sorption data of the titania-metal chalcogenide samples were not further analyzed.

Interestingly, the cadmium titanate crystallizes into an anatase phase of titania and CdS under $\mathrm{H}_{2} \mathrm{~S}$ and brookite phase of titania and CdSe under $\mathrm{H}_{2} \mathrm{Se}$ reactions at RT, Figure 6 and Table S1 (Supporting Information). The $\mathrm{H}_{2} \mathrm{Se}$ reaction of meso$\mathrm{Zn}_{2} \mathrm{TiO}_{4}$ produces rutile phase of titania together with $\mathrm{ZnSe}$ nanocrystallites under an $\mathrm{H}_{2} \mathrm{Se}$ atmosphere at RT. The broad Raman features of the meso-CdTiO 3 disappear and relatively sharper peaks appear due to the anatase (at 146, 196, 393, 511, and $\left.632 \mathrm{~cm}^{-1}\right)^{[19]}$ and brookite phases of titania (at 130, 154, 171, 194, 226, 319, 366, 398, 420, 504, 663, 743, 852, and 896 $\left.\mathrm{cm}^{-1}\right)^{[19]}$ upon reaction under $\mathrm{H}_{2} \mathrm{~S}$ and $\mathrm{H}_{2} \mathrm{Se}$ atmospheres, respectively (Figure 6d). The XRD patterns of these two samples are extremely broad with asymmetric tailings around the anatase and brookite diffraction lines (Figure 6b,c). However, the meso- $\mathrm{Zn}_{2} \mathrm{TiO}_{4}$ films react with the $\mathrm{H}_{2} \mathrm{~S}$ gas extremely slowly (leading to deposition of $\mathrm{S}_{8}$ in the pores therefore it was not investigated any further), but reacts with $\mathrm{H}_{2} \mathrm{Se}$ at RT to produce $m e s o-\mathrm{TiO}_{2}-\mathrm{ZnSe}$ thin films. Figure 6e displays the wide angle XRD pattern of meso- $\mathrm{Zn}_{2} \mathrm{TiO}_{4}$ and $m e s o-\mathrm{TiO}_{2}-\mathrm{ZnSe}$. The diffraction lines of the meso- $\mathrm{TiO}_{2}-\mathrm{ZnSe}$ can be indexed to zinc blend ZnSe nanocrystallites ((111), (220), and (311), observed at $27.2,45.2$, and $53.6^{\circ}, 2 \theta$, respectively) and a rutile phase of titania (not clear from the XRD patterns, due to overlapping of diffraction lines of $\mathrm{ZnSe}$ and an unreacted $\mathrm{Zn}_{2} \mathrm{TiO}_{4}$ ). Notice that one of the most intense (110) line of rutile phase coincides with the (111) line of ZnSe. There are also asymmetric tailings on the diffraction lines at around 36.0 and $54.2^{\circ}$ corresponding to the (101) and (211) planes of rutile phase. Moreover, the Raman spectrum display peaks due to the characteristic vibrational modes of the rutile phase of $\mathrm{TiO}_{2}(143,235$, 430 and $\left.607 \mathrm{~cm}^{-1}\right)^{[19]}$ and longitudinal optical mode ${ }^{[20]}$ (1LO) of ZnSe $\left(250 \mathrm{~cm}^{-1}\right)$, Figure $6 \mathrm{f}$. The red shift from the bulk value $\left(256 \mathrm{~cm}^{-1}\right)$ and the broadening of the LO mode of $\mathrm{ZnSe}$ is due to the quantum confinement effect ${ }^{20]}$ and is consistent with the results of the UV-Vis absorption and XRD data.

The meso-CdTiO ${ }_{3}$, meso- $\mathrm{TiO}_{2}$-CdS, and meso- $\mathrm{TiO}_{2}$-CdSe thin films are crack free, highly transparent and display a uniform colour throughout the films, Figure 7. The absorption edges are sharp and provide the band gap values of $3.88,2.81$, and $2.40 \mathrm{eV}$ for the meso-CdTiO 3 , meso- $\mathrm{TiO}_{2}-\mathrm{CdS}$, and meso-TiO 2 -CdSe thin films, respectively (Figure 8a,c). The observed large blue shifts from the bulk band-gap values are also consistent with the quantum size effects.

The meso- $\mathrm{TiO}_{2}$-CdSe films were further characterized using various TEM techniques. Figure S9 (Supporting Information) displays a series of dark field TEM images of meso- $\mathrm{TiO}_{2}$-CdSe (obtained from $0.57 \mathrm{Cd} / \mathrm{Ti}$ mole ratio thin films) as an example. Both the dark and bright field TEM images of the films clearly show sponge like porosity, which correlates with the absence of the small angle XRD diffraction line(s), Figure S9a-d (Supporting Information). The TEM images of meso- $\mathrm{TiO}_{2}$-CdSe also closely resemble the meso- $\mathrm{CdTiO}_{3}$ films, indicating that there are no morphological changes during the $\mathrm{H}_{2} \mathrm{Se}$ reaction. Figure S9e-g (Supporting Information) are the TEM image of meso- $\mathrm{TiO}_{2}$-CdSe, inverse FFT and FFT of selected areas (I and II in Supporting Information Figure S9e), showing CdSe nanocrystallites. The FFT spots are similar to the electron diffractions and originate from the (111) and (220) planes of zinc blend CdSe. The inverse FFTs of the masked spots clearly display lattice fringes, spaced by 0.352 and $0.262 \mathrm{~nm}$, due to (111) and (220) planes of CdSe nanocrystallites. Combining the data from the three techniques, TEM, XRD, and Raman, clearly shows that the cadmium titanate can be converted to brookite $\mathrm{TiO}_{2}$ and zinc blend $\mathrm{CdSe}$ under an $\mathrm{H}_{2} \mathrm{Se}$ atmosphere at RT. Similarly, the meso-CdTiO 3 can also be exposed to an $\mathrm{H}_{2} \mathrm{~S}$ atmosphere, but this time the resulting products are anatase $\mathrm{TiO}_{2}$ and zinc blend $\mathrm{CdS}$. The fact that the same starting materials, meso$\mathrm{CdTiO}_{3}$, were used for both reactions that produced a brookite and an anatase phases of titania upon reaction with $\mathrm{H}_{2} \mathrm{Se}$ and $\mathrm{H}_{2} \mathrm{~S}$, respectively, indicates that the two different phases of titania are the products of these two different reactions and do not exist in the meso- $\mathrm{CdTiO}_{3}$ films. It is likely that the nanocrystalline $\mathrm{CdTiO}_{3}$ pore-walls are converted into brookite/CdSe and anatase/CdS at RT due to local heat liberated by the $\mathrm{H}_{2} \mathrm{Se}$ and $\mathrm{H}_{2} \mathrm{~S}$ reactions, respectively. Further studies are required 

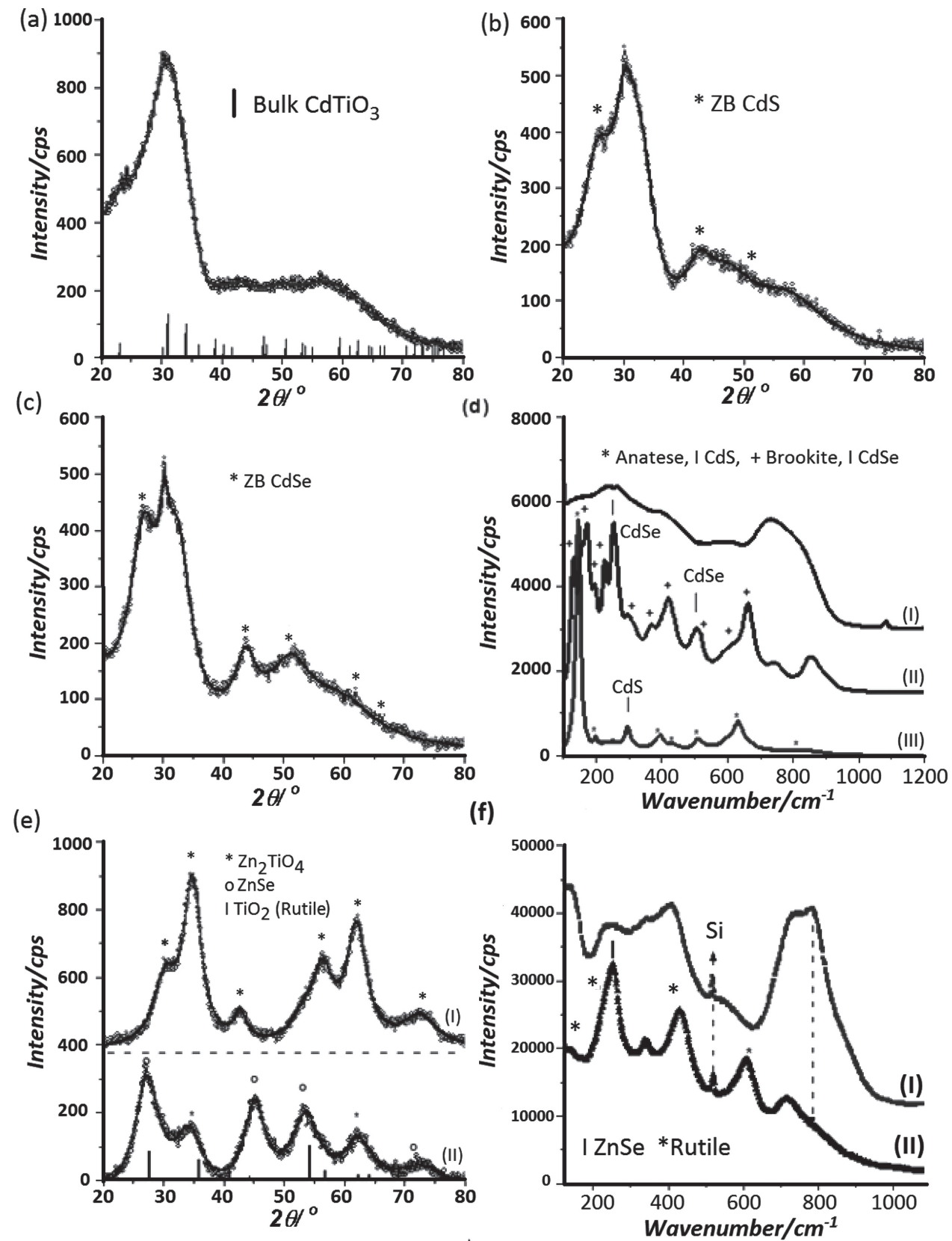

Figure 6. XRD patterns of calcined samples with a $\mathrm{Cd} / \mathrm{Ti}$ mole ratio of 0.86 of a) meso- $\mathrm{CdTiO}_{3}$, b) meso- $\mathrm{TiO}_{2}-\mathrm{CdS}$, and c) $m e s o-\mathrm{TiO}{ }_{2}-\mathrm{CdSe}$. d) $\mathrm{Raman}$ spectra of the calcined samples with a $\mathrm{Cd} / \mathrm{Ti}$ mole ratio of 0.86 of I) meso- $\mathrm{CdTiO}_{3}$, II) meso- $\mathrm{TiO}_{2}-\mathrm{CdSe}$, and III) meso-TiO ${ }_{2}-\mathrm{CdS}$. e) $\mathrm{XRD}$ patterns of the calcined samples with a $\mathrm{Zn} / \mathrm{Ti}$ mole ratio of 0.86 of I) meso- $\mathrm{Zn}_{2} \mathrm{TiO}_{4}$ and II) meso-TiO $-\mathrm{ZnSe}$. f) Raman spectra of the calcined samples with a $\mathrm{Zn} / \mathrm{Ti}$ mole ratio of 0.86 of I) $m e s o-\mathrm{Zn}_{2} \mathrm{TiO}_{4}$ and II) $m e s o-\mathrm{TiO}_{2}-\mathrm{ZnSe}$ (the peak at $520 \mathrm{~cm}^{-1}$ is from the Si substrate).

to elucidate the reaction mechanisms for the formation of the three different phases of nanocrystalline titania at RT, however this is outside the scope of this investigation.

A typical thickness of a single coating, upon calcination, is around 400-600 nm. However, the film thickness can be increased using multiple spin coatings (MSC, each coating follows a calcination step), dip coating (DC), and spray coating (SC). The MSC provides thicker films with multiple thicknesses, see Figure 7. A tri-coated meso- $\mathrm{CdTiO}_{3}$ film, reacted under an $\mathrm{H}_{2} \mathrm{Se}$ atmosphere was also tested for its photoactivity under solar light in a quantum dot (QD) sensitized solar cell. ${ }^{[21]}$ The I-V curve of a cell designed using $1.2 \mu \mathrm{m}$ thick film against a $\mathrm{CuS}_{2}$ electrode, as a counter electrode, obtained by etching brass plate in $\mathrm{HCl}$ solution ${ }^{[21]}$ and dipped into a $0.5 \mathrm{M} \mathrm{Na}_{2} \mathrm{~S}$, $0.2 \mathrm{M} \mathrm{S}_{8}$ and $0.1 \mathrm{M} \mathrm{NaOH}$ solution (as electrolyte), ${ }^{[21]}$ under a $100 \mathrm{~mW} / \mathrm{cm}^{2}$ Nempot 150 Watt with 15 AM-G filter solar simulator is shown in Figure $8 \mathrm{~b}$. The efficiency of this primitive cell is ca. $0.42 \%$ with a fill factor of 0.44 and $1.81 \mathrm{~mA}$ short circuits 


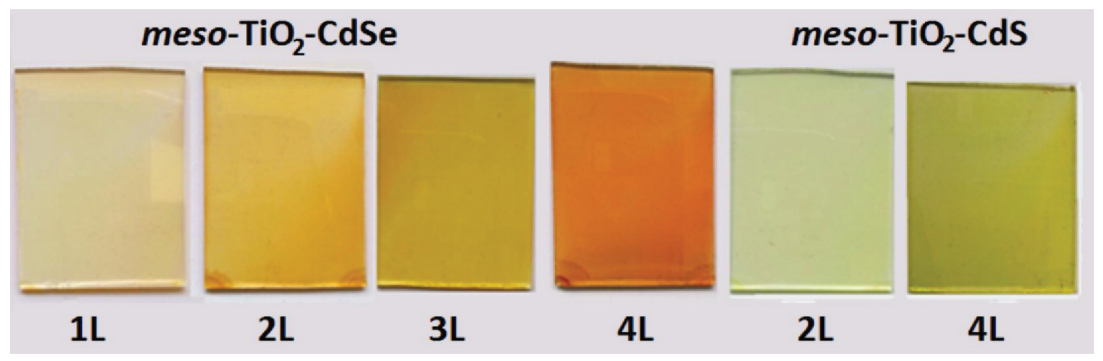

Figure 7. Photographs of meso- $-\mathrm{TiO}_{2}-\mathrm{CdSe}$ and meso- $\mathrm{TiO}_{2}-\mathrm{CdS}$ thin films (as labeled) on the glass microscope slides. The numbers of coatings are labeled under the photographs. (a)

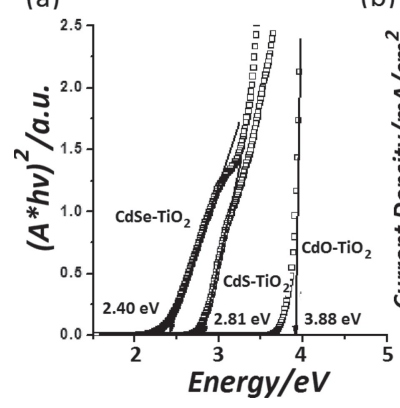

(b)

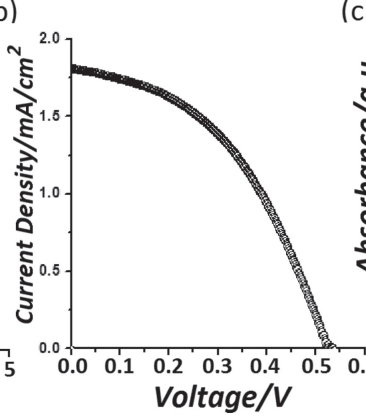

(c)

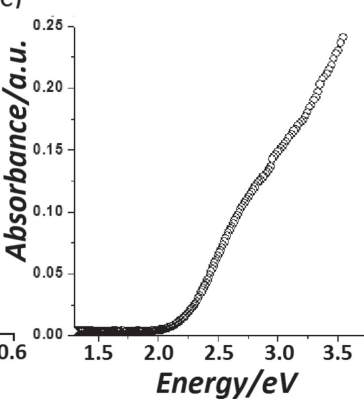

Figure 8. a) The Tauc plots of the absorption spectra of meso- $\mathrm{CdTiO}_{3}$, meso- $\mathrm{TiO}_{2}-\mathrm{CdS}$, and meso- $\mathrm{TiO}_{2}$-CdSe (as labelled on the spectra). b) $I-V$ curve of meso-TiO ${ }_{2}$-CdSe. c) The UV-vis absorption spectrum of meso- $\mathrm{TiO}_{2}$-CdSe (1 layer).

current, Figure $8 \mathrm{~b}$. The efficiency can be further improved by using thicker films and further modification of the cell components. ${ }^{[22,23]}$ Visible light absorption can be further enhanced by preparing thicker films by the DC, SC, and casting methods (Figure 8c); those are out of the scope of this work and will be further investigated.

\section{Conclusions}

MASA is a new, general and effective synthetic method to produce mesoporous metal titanate films. In the MASA process, the titania source undergoes hydrolysis and condensation, where the salt species remain liquid in the media at low temperatures (Scheme 1). The resulting mesostructure is stable above the melting points of the metal salts (this hinders the crystallization) and can be calcined to $450{ }^{\circ} \mathrm{C}$ to produce sponge like mesoporous metal titanates (namely $\mathrm{Zn}_{2} \mathrm{TiO}_{4}$ and $\mathrm{CdTiO}_{3}$ ). The meso- $\mathrm{Zn}_{2} \mathrm{TiO}_{4}$ and meso-CdTiO ${ }_{3}$ samples are stable up to 650 and $550{ }^{\circ} \mathrm{C}$, respectively, and collape and undergo phase change into higly crystalline bulk phases above these temperatures. The mesoporous metal titanate thin films react under $\mathrm{H}_{2} \mathrm{~S}$ or $\mathrm{H}_{2} \mathrm{Se}$ to produce two coupled semiconductors, titania-metal sulfide or titania-metal selenide, respectively, on the pore-walls. Interestingly, these reactions yield nanocrystalline rutile, anatase and brookite phases of titania (all three phases of crystalline titania) at RT from the $\mathrm{Zn}_{2} \mathrm{TiO}_{4} / \mathrm{H}_{2} \mathrm{Se}, \mathrm{CdTiO}_{3} / \mathrm{H}_{2} \mathrm{~S}$ and $\mathrm{CdTiO}_{3} /$ $\mathrm{H}_{2} \mathrm{Se}$ reactions, respectively. The meso- $\mathrm{TiO}_{2}$-CdSe shows photoactivity as good as any QD sensitized mesoporous titania solar cells ${ }^{[23]}$ without optimization of the materials and under measurement conditions that can be further improved. The thicker films can also be obtained using MSC, DC, SC and casting techniques and can also be reacted under $\mathrm{H}_{2} \mathrm{~S}$ and $\mathrm{H}_{2} \mathrm{Se}$ atmospheres at $\mathrm{RT}$ to produce thicker meso- $\mathrm{TiO}_{2}$-MS and meso- $\mathrm{TiO}_{2}$-MSe films. The MASA method is quite general and can be adapted to other metal salts and mixed metal salts to produce other active materials for various applications.

\section{Experimental Section}

Preparation of meso- $\mathrm{TiO}_{2}-\mathrm{MO}(\mathrm{M}=\mathrm{Zn}$ and $\mathrm{Cd})$ Thin Films: A mixture of the required amount of $\left[\mathrm{Zn}\left(\mathrm{H}_{2} \mathrm{O}\right)_{6}\right]\left(\mathrm{NO}_{3}\right)_{2}$ or $\left[\mathrm{Cd}\left(\mathrm{H}_{2} \mathrm{O}\right)_{4}\right]\left(\mathrm{NO}_{3}\right)_{2}, \quad \mathrm{CTAB}$ $(0.29 \mathrm{~g}), \mathrm{C}_{12} \mathrm{EO}_{10}(0.50 \mathrm{~g})$ and ethanol $(7.0 \mathrm{~g})$ was vigorously stirred for 1 day to obtain a clear solution (see Table 1 for details of the amounts of the ingradients). Then concentrated $\mathrm{HNO}_{3}(0.50 \mathrm{~g})$ was added to the above solution and stirred for another $5 \mathrm{~min}$. Finally titanium (IV) butoxide (n-butyl) (1.90 g) was added to the mixture and stirred for additional $5 \mathrm{~min}$. Before spin coating over a substrate the above solution must be homogenous and clear. A few drops of the above solution was put on a substrate using the spin coater and spun for $30 \mathrm{~s}$ at $2000 \mathrm{rpm}$. The thick films were prepared using a spray gun (Max Extra $\mathrm{H}-2000$ ) operated at 3 bar dry air. Immediately after spin or spray coating the films, the samples were put into an oven at $70{ }^{\circ} \mathrm{C}$ and calcined to $450{ }^{\circ} \mathrm{C}$ using a temperature controlled oven by $1{ }^{\circ} \mathrm{C} / \mathrm{min}$ increments. The calcined sample was labeled as meso- $\mathrm{Zn}_{2} \mathrm{TiO}_{4}$ (the $\mathrm{Zn} / \mathrm{Ti}$ mole ratio has been changed among $0.29,0.57,0.86$, and 1.14). The meso- $\mathrm{CdTiO}_{3}$ films were also prepared using the above procedure and the $\mathrm{Cd} / \mathrm{Ti}$ mole ratio was varied between 0.29 and 0.86 .

Preparation of meso-TiO $-\mathrm{MSe}$ and meso-TiO ${ }_{2}-\mathrm{MS}$ Thin Films: The calcined meso- $-\mathrm{Zn}_{2} \mathrm{TiO}_{4}$ or meso- $\mathrm{CdTiO}_{3}$, thin films were inserted into a vacuum chamber, evacuated for 2 min using a rotary pump. The thin films were then exposed to $\mathrm{H}_{2} \mathrm{Se}$ gas (300 torr of $5 \%$, diluted with pure $\mathrm{N}_{2}$ gas) for 15 min to obtain meso- $\mathrm{TiO}_{2}-\mathrm{ZnSe}$ and meso- $\mathrm{TiO}_{2}$-CdSe films, respectively, and to $\mathrm{H}_{2} \mathrm{~S}$ gas (300 torr) for $1 \mathrm{~h}$ to obtain meso- $\mathrm{TiO}_{2}-\mathrm{CdS}$ thin films. Then, the unreacted $\mathrm{H}_{2} \mathrm{Se}$ gas was first evacuated into a $\mathrm{CuO}$ loaded mesoporous silica for 2 min to convert the excess $\mathrm{H}_{2} \mathrm{Se}$ into the copper selenide species. Then, the reaction chamber was evacuated by pumping, using a rotary pump, for $5 \mathrm{~min}$. For the $\mathrm{H}_{2} \mathrm{~S}$ reaction, the unreacted excess $\mathrm{H}_{2} \mathrm{~S}$ gas was pumped from the reaction media for $5 \mathrm{~min}$ before removing the sample from the reaction chamber.

Instrumentation: The FTIR spectra were recorded using a Bruker Tensor 27 model FTIR spectrometer. A Digi Tect TM DLATCS detector with a resolution of $4.0 \mathrm{~cm}^{-1}$ in the $400-4000 \mathrm{~cm}^{-1}$ range was used. The spectra were recorded using the samples coated on silicon wafers or using dry $\mathrm{KBr}$ pallets. The UV-Vis absorption spectra were recorded using thin films coated over quartz substrates and a Thermo Scientific Evolution 300/600 UV-Visible spectrometer. The XRD patterns were recorded on a Rigaku Miniflex Diffractometer using a high power $\mathrm{Cu}-\mathrm{K} \alpha$ source operating at $30 \mathrm{kV} / 15 \mathrm{~mA}$. The POM images were obtained in transmittance mode on a ZEISS Axio Scope A1 Polarizing Optical Microscope. The SEM images were recorded using Hitachi HD-2000 STEM in SEM mode. The high resolution transmittance electron microscope (HRTEM) images were recorded on a FEI Technai G2 F30 and JEOL JEM 2100F at an operating voltage of $200 \mathrm{kV}$. The calcined film samples were scraped and ground in a mortar with $5 \mathrm{~mL}$ of ethanol and dispersed using sonication for $5 \mathrm{~min}$. One drop of the dispersed ethanol solution was put on a TEM grid and dried over a hot-plate. The $\mathrm{N}_{2}(77.4 \mathrm{~K})$ sorption measurements were performed with a TriStar 3000 
automated gas adsorption analyzer (Micrometrics) in a relative pressure range, $P / P_{0}$, from 0.01 to 0.99 . To provide high accuracy and precision in the determination of $P / P_{0}$, the saturation pressure $P_{0}$ was measured over 120 min intervals. The powder samples, which were obtained by scraping approximately 20 glass slides of the films were dehydrated under a ( $\approx 10^{-2}$ torr) vacuum for $3 \mathrm{~h}$ at $300^{\circ} \mathrm{C}$ before measuring in order to remove adsorbed water and volatile species in the pores.

\section{Supporting Information}

Supporting Information is available from the Wiley Online library or from the author.

\section{Acknowledgements}

The authors thank M. Güler and Dr. E. T. Bor for the TEM, Dr. N. Coombs for SEM, and Prof. H. V. Demir and B. Güzeltürk for photoelectrical measurements and to TÜBITAK (under 110T813) for the financial support.

Received: September 18, 2012 Revised: December 4, 2012

Published online: March 13, 2013

[1] a) X. Chen, S. S. Mao, Chem. Rev. 2007, 107, 2891; b) A. A. Ismail, D. W. Bahnemann, J. Mater. Chem. 2011, 21, 11686.

[2] a) M. Grätzel, Nature 2001, 414, 338; b) M. H. Bartl, S. W. Boettcher, K. L. Frindell, G. D. Stucky, Acc. Chem. Res. 2005, 38, 263; c) D. R. Baker, P. V. Kamat, Adv. Funct. Mater. 2009, 19, 805; d) D. Chen, F. Huang, Y. B. Cheng, R. A. Caruso, Adv. Mater. 2009, 21, 2206.

[3] a) D. Zhao, J. Feng, Q. Huo, N. Melosh, G. H. Fredrickson, B. F. Chmelka, G. D. Stucky, Science 1998, 279, 548; b) J. Y. Ying, C. P. Mehnert, M. S. Wong, Angew. Chem. Int. Ed. 1999, 38, 56; c) A. Stein, B. J. Melde, R. C. Schroden, Adv. Mater. 2000, 12, 1403; d) G. J. D. A. Soler-Illia, C. Sanchez, B. Lebeau, J. Patarin, Chem. Rev. 2002, 102, 4093; e) D. Grosso, C. Boissiere, B. Smarsly, T. Brezesinski, N. Pinna, P. A. Albouy, H. Amenitsch, M. Antonietti, C. Sanchez, Nat. Mater. 2004, 3, 797; f) N. Pal, M. Paul, A. Bhaumik, Appl. Catal. A: Gen. 2011, 393, 153.

[4] a) Ö. Dag, I. Soten, Ö. Çelik, S. Polarz, N. Coombs, G. A. Ozin, Adv. Funct. Mater. 2003, 13, 30; b) D. Grosso, G. J. D. A. Soler-Illia, F. Babonneau, C. Sanchez, P. A. Albouy, A. Brunet-Bruneau, A. R. Balkenende, Adv. Mater. 2001, 13, 1085; c) E. L. Crepaldi, G. J. D. A. Soler-Illia, D. Grosso, F. Cagnol, F. Ribot, C. Sanchez, J. Am. Chem. Soc. 2003, 125, 9770; d) S. Y. Choi, M. Mamak, N. Coombs, N. Chopra, G. A. Ozin, Adv. Funct. Mater. 2004, 14, 1085; e) S. Haseloh, S. Y. Choi, M. Mamak, N. Coombs, S. Petrov, N. Chopra, G. A. Ozin, Chem. Commun. 2004, 1460; f) H. M. Luo, C. Wang, Y. S. Yan, Chem. Mater. 2003, 15, 3841; g) S. Y. Choi,
M. Mamak, S. Speakman, N. Chopra, G. A. Ozin, Small 2005, 1, 226; h) J. M. Szeifert, D. Fattakhova-Rohlfing, D. Georgiadou, V. Kalousek, J. Rathousky, D. Kuang, S. Wenger, S. M. Zakeeruddin, M. Grätzel, T. Bein, Chem. Mater. 2009, 21, 1260; i) J. Y. Zhang, Y. H. Deng, D. Gu, S. T. Wang, L. She, R. C. Che, Z. S. Wang, B. Tu, S. H. Xie, D. Y. Zhao, Adv. Energy Mater. 2011, 1, 241; j) K. Ariga, A. Vinu, Y. Yamauchi, Q. Ji, J. P. Hill, Bull. Chem. Soc. Jpn. 2012, 85, 1; k) J. L. Vivero-Escoto, Y.-D. Chiang, K. C.-W. Wu, Y. Yamauchi, Sci. Technol. Adv. Mater. 2012, 13, 013003.

[5] C. J. Brinker, Y. Lu, A. Sellinger, H. Fan, Adv. Mater. 1999, 11, 579.

[6] a) Y. Shen, J. Bao, N. Dai, J. Wu, F. Gu, J. C. Tao, J. C. Zhang, Appl. Surf. Sci. 2009, 255, 3908; b) M. H. Bartl, S. P. Puls, J. Tang, H. C. Lichtenegger, G. D. Stucky, Angew. Chem. Int. Ed. 2004, 43, 3037; c) H. İ. Okur, Y. Türker, Ö. Dag, Langmuir 2010, 26, 538.

[7] a) Y. Yamauchi, T. Oshuna, K. Kuroda, Chem. Mater. 2007, 19, 1335; b) Y. Yamauchi, A. Sugiyama, R. Morimoto, A. Takai, K. Kuroda, Angew. Chem. Int. Ed. 2008, 47, 5371; c) A. Takai, Y. Yamauchi, K. Kuroda, J. Am. Chem. Soc. 2010, 132, 208.

[8] Y. Türker, Ö. Dag, J. Mater. Chem. 2008, 18, 3467.

[9] a) G. S. Li, D. Q. Zhang, J. C. Yu, Environ. Sci. Technol. 2009, 43, 7079; b) Z. -X. Li, F.-B. Shi, Y. Ding, T. Zhang, C.-H. Yan, Langmuir 2011, 27, 14589

[10] C. Albayrak, N. Özkan, Ö. Dag, Langmuir 2011, 27, 870.

[11] a) C. Albayrak, A. M. Soylu, Ö. Dag, Langmuir 2008, 24, 10592; b) C. Albayrak, A. M. Soylu, Ö. Dag, J. Colloid Interface Sci. 2010, $341,109$.

[12] D. Vargas-Florencia, O. Petrov, I. Furo', J. Phys. Chem. B 2006, 110, 3867.

[13] C. Karakaya, Y. Türker, C. Albayarak, Ö. Dag, Chem. Mater. 2011, 23, 3062.

[14] a) Ö. Dag, O. Samarskaya, C. Tura, A. Günay, Ö. Çelik, Langmuir 2003, 19, 3671; b) Ö. Dag, S. Alayoğlu, İ. Uysal, J. Phys. Chem. B 2004, 108, 8439 .

[15] S.-J. Huang, A. B. Walters, M. A. Vannice, J. Catal. 2000, 192, 29.

[16] N. T. Nolan, M. K. Seery, S. C. Pillai, Chem. Mater. 2011, 23, 1496.

[17] Z. Wang, S. K. Saxena, C. S. Zha, Phys. Rev. B 2002, 66, 024103.

[18] S. M. Jang, P. H. Borse, J. S. Lee, K. T. Kim, O. S. Jung, E. D. Jeong, J. S. Bae, M. S. Won, H. G. Kim, Bull. Korean Chem. Soc. 2009, 30, 3021.

[19] G. A. Tompsett, G. A. Bowmaker, R. P. Cooney, J. B. Metson, K. A. Rodgers, J. M. Seakins, J. Raman Spec. 1995, 26, 57.

[20] T. Matsumoto, T. Kato, M. Hosoki, T. Ishida, Jp. J. Appl. Phys. 1987, 26, L576.

[21] a) P. V. Kamat, J. Phys. Chem. C 2008, 112, 18737; b) V. Gonzalez-Pedro, X. Q. Xu, I. Mora-Sero, J. Bisquert, ACS Nano 2010, 4, 5783; c) J. A. Chang, J. H. Rhee, S. H. Im, Y. H. Lee, H.-J. Kim, S. I. Seok, M. K. Nazeeruddin, M. Grätzel, Nano Lett. 2010, 10, 2609.

[22] a) Q. Shen, J. Kobayashi, L. J. Diguna, T. Toyoda, J. Appl. Phys. 2008, 103, 084304; b) H. J. Lee, M. Wang, P. Chen, D. R. Gamelin, S. M. Zakeeruddin, M. Grätzel, M. K. Nazeeruddin, Nano Lett. 2009, 9, 4221.

[23] V. Chakrapani, D. Baker, P. V. Kamat, J. Am. Chem. Soc. 2011, 133, 9607. 